remain aware of the limitations of these capturerecapture methods for estimating the prevalence of disease, carefully choose the situations in which to apply them, and interpret the results cautiously.

\section{REFERENCES}

1. Caughley G, Sinclair ARE. Wildlife Ecology and Management. Boston, MA: Blackwell Scientific Publishers; 1994.

2. Robles SC, Marrett LD, Clarke EA, Risch HA. An application of capture-recapture methods to the estimation of completeness of cancer registration. J Clin Epidemiol 1988;41:495-501.

3. Hook EB, Regal RR. The value of capture-recapture methods even for apparent exhaustive surveys: the need for adjustment for source of ascertainment intersection in attempted complete prevalence studies. Am J Epidemiol 1992;135:1060-1067.

4. Cochi SL, Edmonds LE, Dyer K, et al. Congenital rubella syndrome in the United States, 1970-1985. Am J Epidemiol 1989;129:349-361.

5. Sutter RW, Cochi SL. Pertussis hospitalization and mortality in the United States, 1985-1988. JAMA 1992;267:386-391.

6. McKeganey N, Barnard M, Leyland A, Coote I, Follet E. Female streetworking prostitution and HIV infection in Glasgow. BMJ 1992;305:801-804.

7. Abeni DD, Brancato G, Perucci CA. Capture-recapture to estimate the size of the population of human immunodeficiency virus type 1 infection. Epidemiol 1994;5:410-414.

8. Mastro TD, Kitayaporn D, Weniger BG, et al. Estimating the number of HIV-infected drug users in Bangkok: a capturerecapture method. Am J Public Health 1994;84:1094-1099.

9. Domindo-Salvany A, Hartnoll RL, Maguire A, Suelves JM, Anto JM. Use of capture-recapture to estimate the prevalence of opi- ate addiction in Barcelona, Spain, 1989. Am J Epidemiol 1995;141:567-574.

10. Stephen C, Syrja L. Evaluation of a passive communicable disease surveillance system. BC Health and Disease Surveillance 1995;4:55-62.

11. Egland GM, Perham-Hester KA, Hook EB. Use of capturerecapture analyses in fetal alcohol syndrome surveillance in Alaska. Am J Epidemiol 1995;141:335-341.

12. Seber GAF. The Estimation of Animal Abundance and Related Parameters. 2nd ed. New York, NY: Hafner Press; 1982.

13. Seber GAF. A review of estimating animal abundance. Biometrics 1986;42:267-292.

14. Davis DE, Winstead RL. Estimating the numbers of wildlife population. In: Schemnitz, ed. Wildlife Management Techniques Manual. Washington, DC: The Wildlife Society; 1980:121-146.

15. Hook EB, Regal RR. Effect of variation in probability of ascertainment by sources ('variable catchability') upon capture-recapture estimates of prevalence. Am J Epidemiol 1993;137:11481166.

16. Witte JT, Colton T, Sidel VW. Capture-recapture methods for assessing the completeness of case ascertainment when using multiple information sources. J Chron Dis 1974;27:25-36.

17. Carothers AD. Quantifying unequal catchability and its effect on survival estimates in an actual population. J Anim Ecol 1979;48:863-869

18. Wittes J, Sidel VW. A generalization of the simple capturerecapture model with applications to epidemiological research. J Chron Dis 1968;21:287-301.

19. Begon M. Abuses of mathematical techniques in ecology: applications of Jolly's capture-recapture method. Oikos $1983 ; 40: 155-158$

\title{
Risk of HCV After Occupational Exposure
}

\section{by Gina Pugliese, RN, MS Medical News Editor}

Dr. Vincent Puro of the Spallanzani Hospital in Rome and colleagues from the Italian "Study Group on Occupational Risk of HIV and Other Bloodborne Infections" recently reported a $1.2 \%$ risk of hepatitis $\mathrm{C}$ virus (HCV) infection among healthcare workers (HCWs) following a hollow-bore needlestick to a patient with proven $\mathrm{HCV}$ infection. The prospective study followed $646 \mathrm{HCWs}$ that sustained a percutaneous, mucous membrane, or nonintact skin exposure to blood or body fluids from a source patient known to be seropositive for HCV antibody. HCV seroconversion within 6 months of reported exposures were assessed by secondgeneration enzyme immunoassay and immunoblot assay.

From January 1992 through December 1993, 331 (51\%) hollowbore needlesticks, 105 (16.5\%) suture needle or sharp object injuries, 85 (13\%) mucous membrane contamination, and 125 (19.5\%) skin contaminations were reported. Four HCW seroconversions $(1.2 \%)$ were observed after hollow-bore needlesticks.

The authors note that the absence of seroconversions in the group that sustained injuries with solid sharp objects or contamination of nonintact skin or mucous membrane could be because of the small sample size, as well as lower transmission efficacy by these routes.
Hollow-bore needles do, however, appear to carry a higher risk than other solid devices, probably because of the larger amount of infected material they transfer.

Studies of HCV transmission following occupational exposures have reported a risk of $0 \%$ to $10 \%$-with all reported cases occurring following a needlestick injury. The wide variations in reported rates may be related to differences in study designs, diagnostic methods used, sample size, and by different degrees of infectivity of various $\mathrm{HCV}$ strains.

FROM: Puro V, Petrosillo N, Ippolito G. Risk of hepatitis C seroconversion after occupational exposure in healthcare workers. $A m J$ Infect Control 1995;23:273-277. 